\title{
Cytochalasins from cultures of endophytic fungus Phoma multirostrata EA-12
}

\author{
Zi-ming Chen ${ }^{1}$, He-Ping Chen ${ }^{1,2}$, Yan $\mathrm{Li}^{1}$, Tao Feng ${ }^{1}$ and Ji-Kai Liu ${ }^{1}$
}

Two new cytochalsians, multirostratin A (1) and 20-oxo-deoxaphomin (2), together with five known analogues (3-7), were obtained from the endophytic fungus Phoma multirostrata EA-12. The structures of 1 and 2 were elucidated by MS and 1D- and 2D-NMR spectroscopic data analyses, as well as by comparison of data with those of analogues reported in the literature. Compounds 1 and 2 showed moderate cytotoxicity against five tumor cell lines (HL-60, A-549, SMMC-7721, MCF-7 and SW-480).

The Journal of Antibiotics (2015) 68, 23-26; doi:10.1038/ja.2014.87; published online 25 June 2014

\section{INTRODUCTION}

Endophytic fungi have been proved to be a productive source of structurally diverse and biologically active secondary metabolites. ${ }^{1-3}$ In our effort to search for structurally interesting and bioactive natural products, $>200$ strains of endophytic fungi isolated from Eupatorium adenophorum were preliminarily screened for their toxicity against brine shrimp (Artemia salina). In these investigated fungi, one strain, named EA-12, identified as Phoma multirostrata was found lethal to brine shrimp. Chemical investigation on cultures of $P$. multirostrata led to the isolation of two new cytochalsians, multirostratin A (1) and 20-oxo-deoxaphomin (2), together with five known analogues, deoxaphomin (3), ${ }^{4}$ cytochalasin A (4), ${ }^{5}$ cytochalasin B (5), ${ }^{5}$ cytochalasin $\mathrm{Z}_{2}(\mathbf{6})^{6}$ and cytochalasin $\mathrm{F}(\mathbf{7})$ (Figure 1). ${ }^{7}$ The new structrures were elucidated by extensive spectroscopic methods, while the known analogues were identified by comparison data with those reported in the literature. Compound 1 was the first cytochalasin with a macrocyclic ring including a furan moiety. The new compounds $\mathbf{1}$ and $\mathbf{2}$ showed significant cytotoxicities against five tumor cell lines of HL-60, A-549, SMMC-7721, MCF-7 and SW-480.

\section{RESULTS AND DISCUSSION}

Compound 1 was obtained as white, amorphous solid, which was assigned the molecular formula $\mathrm{C}_{29} \mathrm{H}_{35} \mathrm{NO}_{3}$ from its HR-EI-MS $(\mathrm{m} / \mathrm{z}$ $445.2622[\mathrm{M}]^{+}$, calcd for $\mathrm{C}_{29} \mathrm{H}_{35} \mathrm{NO}_{3}, 445.2617$ ), indicating $13^{\circ}$ of unsaturation. Its IR spectrum exhibited absorption bands for a hydroxy $\left(3424 \mathrm{~cm}^{-1}\right)$, amide carbonyl $\left(1700 \mathrm{~cm}^{-1}\right)$, olefinic bond $\left(1641 \mathrm{~cm}^{-1}\right)$ and phenyl $\left(1606,1023,701 \mathrm{~cm}^{-1}\right)$ groups. 1D NMR and HSQC spectra of 1 revealed 29 carbon signals, including 2 methyls, 6 methylenes (one exo-methylene), 15 methines (one oxymethine) and 6 quarternary carbons (including three carbonyls) (Table 1). The ${ }^{1} \mathrm{H}$ NMR spectrum showed two methyl signals at $\delta_{\mathrm{H}}$
$0.92(3 \mathrm{H}, \mathrm{d}, J=6.9 \mathrm{~Hz}, \mathrm{H}-24)$ and $0.96(3 \mathrm{H}, \mathrm{d}, J=6.7 \mathrm{~Hz}, \mathrm{H}-11)$, two exocyclic $\mathrm{CH}_{2}=$ group at $\delta_{\mathrm{H}} 5.10(1 \mathrm{H}, \mathrm{s}, \mathrm{H}-12 \mathrm{a})$ and $5.28(1 \mathrm{H}, \mathrm{s}$, $\mathrm{H}-12 \mathrm{~b})$, a double bond group at $\delta_{\mathrm{H}} 5.43(1 \mathrm{H}, \mathrm{m}, \mathrm{H}-14)$ and $6.07(1 \mathrm{H}$, ddd, $J=15.4,9.8,1.5 \mathrm{~Hz}, \mathrm{H}-13$ ) and a monosubstituted phenyl group at $\delta_{\mathrm{H}} 7.12\left(2 \mathrm{H}, \mathrm{d}, J=7.0 \mathrm{~Hz}, \mathrm{H}-2^{\prime}, 6^{\prime}\right), 7.23\left(1 \mathrm{H}, \mathrm{t}, J=7.0 \mathrm{~Hz} \mathrm{H}-4^{\prime}\right)$ and $7.30\left(2 \mathrm{H}, \mathrm{d}, J=7.0 \mathrm{~Hz}, \mathrm{H}-3^{\prime}, 5^{\prime}\right)$. In addition, the presence of a 2,5-disubstituted furan moiety in $\mathbf{1}$ was assumed by the NMR signals at $\delta_{\mathrm{H}} 5.93(1 \mathrm{H}, \mathrm{d}, J=3.0 \mathrm{~Hz}, \mathrm{H}-21), 6.10(1 \mathrm{H}, \mathrm{d}, J=3.0 \mathrm{~Hz} \mathrm{H}-22)$ and at $\delta_{\mathrm{C}} 106.2(\mathrm{C}-22), 107.2(\mathrm{C}-21), 153.2(\mathrm{C}-23)$ and $156.2(\mathrm{C}-20)$.

Analysis of the ${ }^{1} \mathrm{H}-{ }^{1} \mathrm{H}$ COSY spectrum gave two $\mathrm{C}$-linkage fragments: C-10/C-3/C-4/C-5/11-Me and C-7/C-8/C-13/C-14/C-15/ $\mathrm{C}-16 / \mathrm{C}-17$ or $24-\mathrm{Me} / \mathrm{C}-18 / \mathrm{C}-19$, as shown in bold in Figure 2. In the HMBC spectrum (Figure 2), the correlation of $\mathrm{H}-4$ and $\mathrm{H}-8$ to C-9, C-1 and C-23 indicated that C-1, C-4, C-8 and C-23 were all connected to C-9, and the correlation of $\mathrm{H}-12$ to $\mathrm{C}-5, \mathrm{C}-6$ and C-7, together with $\mathrm{H}-3$ to $\mathrm{C}-3, \mathrm{C}-4$ and $\mathrm{C}-5$, established an isoindolone moiety in 1. Furthermore, the HMBC correlation of $\mathrm{H}-21$ and $\mathrm{H}-22$ to C-8, C-9, C-19 and C-20, indicating a furan moiety located between C-19 and C-23 (Figure 2). The monosubstituted phenyl group was connected to the isoindolone moiety via $\mathrm{C}-10$ on the correlations of aromatic proton signal at $\delta_{\mathrm{H}} 7.12\left(\mathrm{H}-2^{\prime}\right)$, with the carbon signal at $\delta_{\mathrm{C}} 44.2$ (C-10). Thus the planar structure of 1 was established.

The relative configuration of $\mathbf{1}$ was established by a combination of coupling constant and ROESY data. In the ${ }^{1} \mathrm{H}$ NMR spectrum, the large coupling constant $(J=10.2 \mathrm{~Hz})$ for $\mathrm{H}-7$ and $\mathrm{H}-8$ suggested the axial-axial orientation of the proton pair. The E-geometry of the $\Delta^{13}$-double bond was deduced from the large coupling constant observed for $\mathrm{H}-13(\mathrm{~J}=14.7 \mathrm{~Hz})$. In the ROESY spectrum, the correlations of $\mathrm{H}-3 / \mathrm{H}_{3}-11, \mathrm{H}-5 / \mathrm{H}-4$ and $\mathrm{H}-5 / \mathrm{H}-8$ were observed, which indicated that $\mathrm{H}-3, \mathrm{H}_{3}-11$ and $\mathrm{H}-7$ were in the same orientation $(\alpha)$, whereas $\mathrm{H}-4, \mathrm{H}-5$ and $\mathrm{H}-8$ were in the opposite

${ }^{1}$ State Key Laboratory of Phytochemistry and Plant Resources in West China, Kunming Institute of Botany, Chinese Academy of Sciences, Kunming, PR China and ${ }^{2}$ University of Chinese Academy of Sciences, Beijing, PR China

Correspondence: Dr T Feng or Professor J-K Liu State Key Laboratory of Phytochemistry and Plant Resources in West China, Kunming Institute of Botany, Chinese Academy of Sciences, 134 Lanhei Road, Kunming 605201, China.

E-mail: fengtao@mail.kib.ac.cn or jkliu@mail.kib.ac.cn

Received 5 March 2014; revised 21 May 2014; accepted 28 May 2014; published online 25 June 2014 


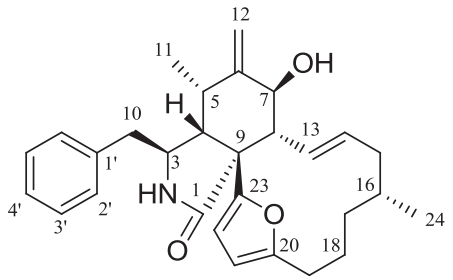

1

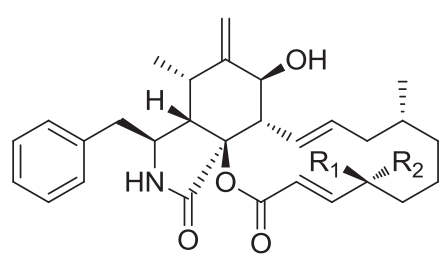

$4 \mathrm{R}_{1}+\mathrm{R}_{2}==\mathrm{O}$

$5 \mathrm{R}_{1}=\mathrm{OH}, \mathrm{R}_{2}=\mathrm{H}$

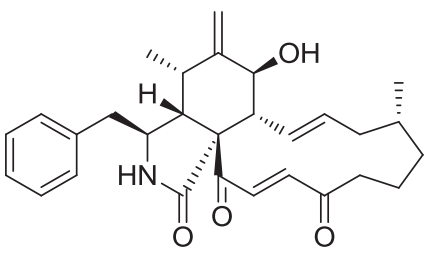

2

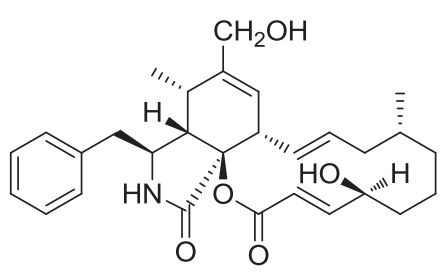

6

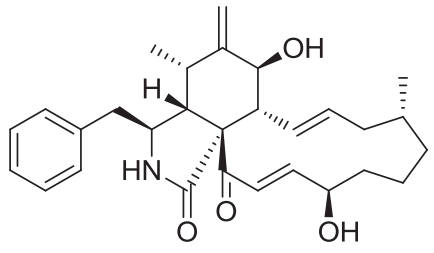

3

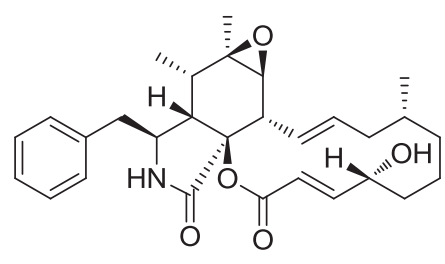

7

Figure 1 Structures of cytochalasins (1-7) from the endophytic fungus Phoma multirostrata.

direction $(\beta)$ (Figure 2). The correlations of $\mathrm{H}-7 / \mathrm{H}-13, \mathrm{H}-14 / \mathrm{H}-15 \mathrm{~b}$, $\mathrm{H}-15 \mathrm{~b} / \mathrm{H}-14, \mathrm{H}-15 \mathrm{~b} / \mathrm{H}-16$ and $\mathrm{H}-15 \mathrm{a} / \mathrm{H}_{3}-24$ indicated that $\mathrm{H}-13$ and $\mathrm{H}_{3}-24$ were $\alpha$-oriented, while $\mathrm{H}-14$ and $\mathrm{H}-16$ were $\beta$-oriented. Consequently, the structure of 1 was established and given the name multirostratin A.

Compound 2 was obtained as white, amorphous solid. Its molecular formula was determined as $\mathrm{C}_{29} \mathrm{H}_{35} \mathrm{NO}_{3}$ from the positive HREIMS molecular ion peak at $\mathrm{m} / z 461.2587[\mathrm{M}]^{+}$, indicating $13^{\circ}$ of unsaturation. The NMR spectral data of 2 (Table 1) resembled to the known analogue deoxaphomin (3) except that the ${ }^{13} \mathrm{C}$ signal at $74.0 \mathrm{ppm}$ (C-20) in 3 was changed to 204.2 p.p.m. in 2, suggesting that a keto carbon atom instead of an oxygen-bearing methine existed in 2. In addition, the ${ }^{1} \mathrm{H}$ signal of $\mathrm{H}-21$ was split into a doublet $(J=16.2 \mathrm{~Hz})$ instead of a double doublet $(J=15.3,8.1 \mathrm{~Hz})$ in 3 . This was in accordance with the HMBC correlations from $\mathrm{H}-21\left(\delta_{\mathrm{H}} 7.70\right.$ $(1 \mathrm{H}, \mathrm{d}, J=16.2 \mathrm{~Hz}))$ and $\mathrm{H}-22\left(\delta_{\mathrm{H}} 6.85(1 \mathrm{H}, \mathrm{d}, J=16.2 \mathrm{~Hz})\right)$ to $\mathrm{C}-20$ $\left(\delta_{\mathrm{C}} 204.2\right)$ and $\mathrm{C}-19\left(\delta_{\mathrm{C}} 41.5\right)$ (Figure 2$)$. The other correlations in the $\mathrm{HMBC}$ and ${ }^{1} \mathrm{H}-{ }^{1} \mathrm{H}$ COSY spectra as shown in Figure 2 also confirmed the connectivities in compound 2 . The relative configuration of $\mathbf{2}$ was established by a combination of coupling constant and ROESY experiment. In the ${ }^{1} \mathrm{H}$ NMR spectrum, the large coupling constant $(J=10.5 \mathrm{~Hz})$ for $\mathrm{H}-7$ and $\mathrm{H}-8$ suggested the axial-axial orientation of the proton pair. The E-geometry of the $\Delta^{13}$ and $\Delta^{21}$ double bonds was deduced from the large coupling constant observed for $J_{\mathrm{H}-13, \mathrm{H}-14}=15.2 \mathrm{~Hz}$ and $J_{\mathrm{H}-21, \mathrm{H}-22}=16.2 \mathrm{~Hz}$. The ROESY spectrum of $\mathbf{2}$ displayed similar patterns to those of $\mathbf{1}$, which suggested that the relative configurations of the chiral centers in 2 were the same to those of $\mathbf{1}$ (Figure 2). Consequently, compound $\mathbf{2}$ was identified as 20-oxo-deoxaphomin.

Compounds 1 and 2 showed a certain cytotoxic activities against HL-60, A-549, SMMC-7721, MCF-7 and SW-480, the $\mathrm{IC}_{50}$ values varied between 7.7 and $15.8 \mu \mathrm{M}$, as listed in Table 2 .

In summary, cytochalasins are a group of polyketide synthases-non ribosomal peptide synthetases (PKS-NRPS) hybrid fungal metabolites that have been isolated from different genera of fungi, such as Phomopsis, ${ }^{8}$ Aspergillus, ${ }^{9}$ Spicaria,${ }^{10}$ Xylaria,${ }^{11}$ Periconia,${ }^{12}$ etc. They display a wide range of biological activities, including cytotoxic, ${ }^{11,12}$ antibiotic, $^{13}$ inhibition of HIV-1 protease $^{14}$ and phytotoxic activities; ${ }^{15}$ their most unusual property is the ability to cause cells to extrude their nuclei, leading to the formation of nuclei free cells. In general, cytochalasins are structurally characterized by a highly substituted isoindolone fused with an 11- to 13-membered carbocyclic or 12- to 14-membered lactone rings, and most recently, an unprecedented 9-membered carbocyclic rings. ${ }^{12}$ To date, $>100$ cytochalasins and derivatives have been isolated from a range of fungi. To the best of our knowledge, multirostratin A (1) was the first example with a macrocyclic ring including a furan moiety.

\section{METHODS}

\section{General experimental procedures}

Optical rotations were taken on a Horiba SEAP-300 polarimeter (Horiba, Kyoto, Japan). UV spectra were obtained on a Hitachi UV 210A spectrophotometer (Shimadzu, Kyoto, Japan). IR spectra were measured on a Bio-Rad FTS-135 spectrometer with $\mathrm{KBr}$ pellets (SPECTRO, Kleve, Germany). 1D and 2D NMR spectra were recorded on a Brucker AM-400 or DRX-500 NMR spectrometer (Bruker, Karlsruher, Germany). HR-EI-MS were recorded on a Waters Auto Premier P776 spectrometer (Waters, Milford, MA, USA). Preparative HPLC was performed on an Agilent 1100 series with a Zorbax SB-C18 $(5 \mu \mathrm{m}, 9.4 \times 150 \mathrm{~mm})$ column (Agilent Technologies, Santa Clara, CA, USA). Preparative MPLC was performed on a Buchi apparatus equipped with a Buchi fraction collector C-660, a Buchi pump module C-605 and a manager C-615 (Büchi Labortechnik AG, Flawil, Switzerland). Column chromatography (CC) was performed on silica gel (200-300 mesh; Qingdao Marine Chemical Inc., Qingdao, People's Republic of China) and Sephadex LH-20 (Amersham Biosciences, Upssala, Sweden). Fractions were monitored by TLC, and spots were visualized by heating silica gel plates sprayed with $10 \% \mathrm{H}_{2} \mathrm{SO}_{4}$ in EtOH.

\section{Fungal material}

The fungus $P$. multirostrata EA-12 was isolated from fresh leaves of E. Adenophorum collected in Kunming Institute of Botany, Kunming, Yunnan province, PR China in July 2012. The fungus was identified by observing the morphological characteristics and analysis of the internal transcribed spacer regions. The result from the BLAST search indicated that the sequence was the same $(100 \%)$ as that for the sequence of P. multirostrata (compared with EF585392.1). The strain is preserved at the Kunming Institute of Botany, Chinese Academy of Sciences (No. F2012076).

\section{Fermentation, extraction and isolation}

This fungal strain was cultured on potato dextrose agar medium at $25^{\circ} \mathrm{C}$ for 10 days. The agar plugs were inoculated in 500-ml Erlenmeyer flasks, each 
Table $1{ }^{1} \mathrm{H}$ and ${ }^{13} \mathrm{C}$ NMR spectroscopic data of $1-3$

\begin{tabular}{|c|c|c|c|c|c|c|}
\hline & \multicolumn{2}{|l|}{$1^{\mathrm{a}}$} & \multicolumn{2}{|l|}{$2^{a}$} & \multicolumn{2}{|l|}{$3^{b}$} \\
\hline & $\delta_{H}(J$ in $H z)$ & $\delta_{C} m u l t$ & $\delta_{H}(J$ in $H z)$ & $\delta_{C} m u l t$ & $\delta_{H}(J$ in $H z)$ & $\delta_{C} m u l t$ \\
\hline 1 & & $174.7 \mathrm{~s}$ & & $172.7 \mathrm{~s}$ & & $176.5 \mathrm{~s}$ \\
\hline 3 & 3.39 t (7.3) & $53.5 d$ & $3.35 \mathrm{~m}$ & $53.6 \mathrm{~d}$ & 3.38 m & $54.2 d$ \\
\hline 4 & $2.72 \mathrm{~m}$ & $49.2 \mathrm{~d}$ & $3.11 \mathrm{t}(4.4)$ & $45.8 d$ & $2.98 \mathrm{dd}(6.2,1.4)$ & $46.5 d$ \\
\hline 5 & $2.93 \mathrm{~m}$ & $31.8 \mathrm{~d}$ & $2.84 \mathrm{~m}$ & $32.3 \mathrm{~d}$ & $2.72 \mathrm{~m}$ & $32.4 \mathrm{~d}$ \\
\hline 6 & & $147.8 \mathrm{~s}$ & & $148.1 \mathrm{~s}$ & & $151.0 \mathrm{~s}$ \\
\hline 7 & $4.03 \mathrm{~d}(10.2)$ & $70.6 \mathrm{~d}$ & 3.96 d (10.5) & $70.1 \mathrm{~d}$ & 3.94 d (9.8) & $73.0 \mathrm{~d}$ \\
\hline 8 & 2.58 t (10.2) & $53.0 \mathrm{~d}$ & $2.45 \mathrm{~m}$ & $50.9 \mathrm{~d}$ & 2.55 t (9.8) & $51.6 \mathrm{~d}$ \\
\hline 9 & & $50.2 \mathrm{~s}$ & & $62.5 \mathrm{~s}$ & & $63.8 \mathrm{~s}$ \\
\hline $10 a$ & $2.73 \mathrm{~m}$ & $44.2 \mathrm{t}$ & $2.48 \mathrm{~m}$ & $44.5 \mathrm{t}$ & 2.40 dd $(13.1,8.3)$ & $43.9 \mathrm{t}$ \\
\hline $10 b$ & & & $2.82 \mathrm{~m}$ & & 2.72 dd $(13.1,6.7)$ & \\
\hline 11 & $0.96 \mathrm{~d}(6.7)$ & $13.2 \mathrm{q}$ & $1.13 \mathrm{~d}(6.7)$ & $14.3 \mathrm{q}$ & $0.73 \mathrm{~d}(6.7)$ & $13.2 \mathrm{q}$ \\
\hline $12 \mathrm{a}$ & $5.10 \mathrm{~s}$ & $115.1 \mathrm{t}$ & $5.16 \mathrm{~s}$ & $114.3 \mathrm{t}$ & $5.03 \mathrm{~s}$ & $114.1 \mathrm{t}$ \\
\hline $12 b$ & $5.28 \mathrm{~s}$ & & $5.37 \mathrm{~s}$ & & $5.18 \mathrm{~s}$ & \\
\hline 13 & $6.41 \mathrm{dd}(15.4,10.0)$ & $128.7 \mathrm{~d}$ & 6.07 ddd $(15.4,9.8,1.5)$ & $127.3 \mathrm{~d}$ & 6.06 ddd $(15.2,9.6,1.8)$ & $128.1 \mathrm{~d}$ \\
\hline 14 & $5.23 \mathrm{~m}$ & $134.8 \mathrm{~d}$ & $5.43 \mathrm{~m}$ & $137.6 \mathrm{~d}$ & $5.26 \mathrm{~m}$ & $137.5 \mathrm{~d}$ \\
\hline $15 a$ & $1.98 \mathrm{~m}$ & $39.1 \mathrm{t}$ & $1.90 \mathrm{~m}$ & $40.2 \mathrm{t}$ & 1.80 m & $40.5 \mathrm{t}$ \\
\hline $15 b$ & $2.15 \mathrm{~m}$ & & 2.13 dd $(14.2,2.3)$ & & $2.08 \mathrm{dd}(14.1,2.5)$ & \\
\hline 16 & $1.65 \mathrm{~m}$ & $31.5 \mathrm{~d}$ & $1.54 \mathrm{~m}$ & $31.9 \mathrm{~d}$ & $1.54 \mathrm{~m}$ & $34.2 \mathrm{~d}$ \\
\hline $17 a$ & $0.87 \mathrm{~m}$ & $30.5 \mathrm{t}$ & $1.17 \mathrm{~m}$ & $32.8 \mathrm{t}$ & $1.10 \mathrm{~m}$ & $35.1 \mathrm{t}$ \\
\hline $17 b$ & $0.98 \mathrm{~m}$ & & 1.38 ddd $(14.1,9.8,4.0)$ & & $1.28 \mathrm{~m}$ & \\
\hline $18 a$ & $1.48 \mathrm{~m}$ & $21.0 \mathrm{t}$ & $1.59 \mathrm{~m}$ & $20.9 t$ & $1.11 \mathrm{~m}$ & $19.8 \mathrm{t}$ \\
\hline $18 b$ & $1.85 \mathrm{~m}$ & & $1.88 \mathrm{~m}$ & & $1.40 \mathrm{~m}$ & \\
\hline 19a & $2.41 \mathrm{~m}$ & $27.4 \mathrm{t}$ & $2.47 \mathrm{~m}$ & $41.5 \mathrm{t}$ & 1.93 m & $36.3 \mathrm{t}$ \\
\hline $19 b$ & $2.72 \mathrm{~m}$ & & $2.76 \mathrm{~m}$ & & $1.44 \mathrm{~m}$ & \\
\hline 20 & & $156.2 \mathrm{~s}$ & & $204.2 \mathrm{~s}$ & $4.16 \mathrm{~m}$ & $74.0 \mathrm{~d}$ \\
\hline 21 & 5.93 d (3.0) & $107.2 \mathrm{~d}$ & $7.70 \mathrm{~d}(16.2)$ & $133.1 \mathrm{~d}$ & $6.68 \mathrm{dd}(16.2,8.1)$ & $149.8 d$ \\
\hline 22 & $6.10 \mathrm{~d}(3.0)$ & $106.2 \mathrm{~d}$ & $6.85 \mathrm{~d}(16.2)$ & $138.2 d$ & $6.91 \mathrm{~d}(16.2)$ & $125.9 \mathrm{~d}$ \\
\hline 23 & & $153.2 \mathrm{~s}$ & & $197.4 \mathrm{~s}$ & & $198.8 \mathrm{~s}$ \\
\hline 24 & 0.92 d (6.9) & $21.0 \mathrm{q}$ & $0.92 \mathrm{~d}(6.6)$ & $20.9 q$ & $0.91 \mathrm{~d}(6.8)$ & 20.9 q \\
\hline $1^{\prime}$ & & $137.6 \mathrm{~s}$ & & $137.0 \mathrm{~s}$ & & $138.2 \mathrm{~s}$ \\
\hline $2^{\prime}, 6^{\prime}$ & 7.12 d (7.0) & $129.2 \mathrm{~d}$ & $7.12 \mathrm{~d}(7.0)$ & $129.3 \mathrm{~d}$ & $7.14 \mathrm{~d}(7.0)$ & $130.8 d$ \\
\hline $3^{\prime}, 5^{\prime}$ & 7.30 t (7.0) & $128.9 \mathrm{~d}$ & 7.30 t (7.0) & $129.1 \mathrm{~d}$ & 7.30 t (7.0) & $129.6 \mathrm{~d}$ \\
\hline $4^{\prime}$ & 7.23 t (7.0) & $127.0 \mathrm{~d}$ & 7.23 t (7.0) & $127.3 \mathrm{~d}$ & 7.23 t (7.0) & $127.8 \mathrm{~d}$ \\
\hline $\mathrm{NH}$ & $5.63 \mathrm{~s}$ & & $5.66 \mathrm{~s}$ & & & \\
\hline
\end{tabular}

Recorded in $\mathrm{CDCl}_{3}$ at $500 \mathrm{MHz}$ for ${ }^{1} \mathrm{H}$ and $100 \mathrm{MHz}$ for ${ }^{13} \mathrm{C}$.

becorded in methanol- $d_{4}$ at $400 \mathrm{MHz}$ for ${ }^{1} \mathrm{H}$ and $100 \mathrm{MHz}$ for ${ }^{13} \mathrm{C}$.

containing $100 \mathrm{ml}$ of potato dextrose media. Flask cultures were incubated at $28{ }^{\circ} \mathrm{C}$ on a rotary shaker at 160 r.p.m. for 2 days as seed culture. Sixty $500-\mathrm{ml}$ Erlenmeyer flasks each containing $150 \mathrm{ml}$ of potato dextrose broth were individually inoculated with $25 \mathrm{ml}$ of seed culture and incubated at $25^{\circ} \mathrm{C}$ on a rotary shaker at 160 r.p.m. for 15 days.

The fermented broth was filtered through cheesecloth to separate supernatant and mycelia. The former was extracted with EtOAc $(3 \times 15$ liter $)$, and the organic solvent was evaporated to dryness under vacuum to afford the extract of the supernatant. The mycelia was extracted with acetone $(3 \times 1$ liter $)$ and then concentrated under reduced pressure to afford an aqueous solution. The aqueous solution was extracted with EtOAc $(3 \times 1$ liter $)$, and the EtOAc solution was evaporated to dryness under vacuum to obtain the crude extract of the mycelia. Both extracts were combined to yield a residue $(11.0 \mathrm{~g})$. The residue was subjected to silica gel CC with a gradient elution system of $\mathrm{CHCl}_{3} /$ $\mathrm{MeOH}$ (from 100:0 to 0:100, V/V) to obtain seven fractions. Fraction B was separated to six subfractions $(\mathrm{B} 1 \sim \mathrm{B} 6)$ by MPLC eluted with $\mathrm{MeOH} / \mathrm{H}_{2} \mathrm{O}$ (from 0:100 to 100:0, V/V). Fraction B2 (1.8g) was separated by silica gel CC eluted with $\mathrm{CHCl}_{3} / \mathrm{MeOH}$ (from 100:1 to $96: 4, \mathrm{~V} / \mathrm{V}$ ) to afford $5(1.4 \mathrm{~g}$ ). Fraction B3 was further separated by preparative HPLC $\left(\mathrm{MeCN} / \mathrm{H}_{2} \mathrm{O}\right.$, from $30: 70$ to $60: 40, \mathrm{~V} / \mathrm{V}, 10 \mathrm{ml} \mathrm{min}^{-1}$ in $\left.30 \mathrm{~min}\right)$ to yield $4\left(8.0 \mathrm{mg}, \mathrm{t}_{R}=16.2 \mathrm{~min}\right)$ and $6\left(24.5 \mathrm{mg}, \mathrm{t}_{R}=14.8 \mathrm{~min}\right)$. Fraction B5 $(1.7 \mathrm{~g})$ was separated by silica gel CC eluted with $\mathrm{CHCl}_{3} / \mathrm{Me}_{2} \mathrm{CO}$ (from 20:1 to 3:1, V/V) to obtain five subfractions $(\mathrm{B} 5 \mathrm{a} \sim \mathrm{B} 5 \mathrm{e})$. Fraction $\mathrm{B} 5 \mathrm{~b}(150 \mathrm{mg})$ was further separated by preparative HPLC $\left(\mathrm{MeCN} / \mathrm{H}_{2} \mathrm{O}\right.$, from $25: 75$ to $60: 40, \mathrm{~V} / \mathrm{V}, 10 \mathrm{ml} / \mathrm{min}$ in $35 \mathrm{~min})$ to afford $1\left(5.2 \mathrm{mg}, t_{R}=29.2 \mathrm{~min}\right), 2\left(4.8 \mathrm{mg}, t_{R}=19.0 \mathrm{~min}\right)$ and 7 ( $\left.3.1 \mathrm{mg}, t_{R}=25.6 \mathrm{~min}\right)$. Fraction B5c ( $88 \mathrm{mg}$ ) was subjected to sephdax LH-20 $\left(\mathrm{CHCl}_{3} / \mathrm{MeOH}, 1: 1, \mathrm{~V} / \mathrm{V}\right)$ and silica gel $\mathrm{CC}\left(\mathrm{CHCl}_{3} / \mathrm{MeOH}, 20: 1\right)$ to yield 3 (11.2 mg).

\section{Physico-chemical properties}

Multirostratin A (1): white, amorphous solid; $[\alpha] 25 \mathrm{D}+118.0($ c $0.20 \mathrm{MeOH})$; $\mathrm{UV}(\mathrm{MeOH}) \lambda_{\max }(\log \varepsilon) 203$ (4.38) nm; IR (KBr) $v_{\max }$ 3424, 2949, 1700, 1641, 1453, 1023, 978, $701 \mathrm{~cm}^{-1} .{ }^{1} \mathrm{H}$ and ${ }^{13} \mathrm{C}$ NMR data (see Table 1); HR-ESI-MS (pos.) $\mathrm{m} / z 445.2622$ (calcd for $\mathrm{C}_{29} \mathrm{H}_{35} \mathrm{NO}_{3}, 445.2617$ ).

20-Oxo-deoxaphomin (2): white, amorphous solid; [ $\alpha] 25 \mathrm{D}+61.1$ ( $c 0.21$ $\mathrm{MeOH}) ; \mathrm{UV}(\mathrm{MeOH}) \lambda_{\max }(\log \varepsilon) 203(4.35), 233(3.93) \mathrm{nm}$; IR (KBr) $v_{\max }$ $3423,2923,1691,1662,1454,1275,1024,973 \mathrm{~cm}^{-1}$. ${ }^{1} \mathrm{H}$ and ${ }^{13} \mathrm{C}$ NMR data (see Table 1); HR-ESI-MS (pos.) $\mathrm{m} / z 461.2566$ (calcd for $\mathrm{C}_{29} \mathrm{H}_{35} \mathrm{NO}_{4}$, 461.2578).

\section{Cytotoxic activity}

Cytotoxicities of multirostratin A (1) and 20-oxo-deoxaphomin (2) were assayed against five tumor cell lines, including SK-BR-3 (breast cancer cell 

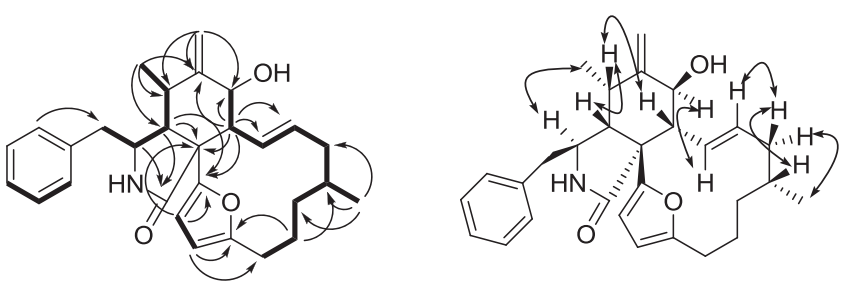

1
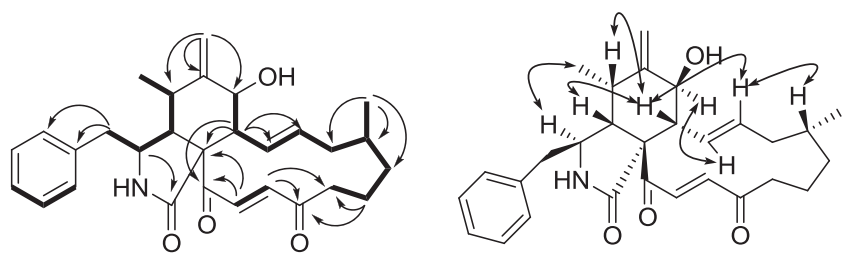

2

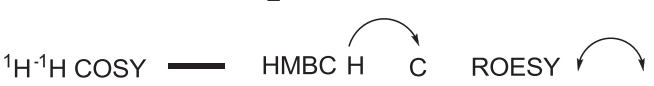

Figure 2 Selected 2D NMR correlations of 1 and 2.

Table 2 Cytotoxicity of compounds 1 and 2 against five cancer cell lines $\left(\mathrm{IC}_{50} \mu \mathrm{M}\right)$

\begin{tabular}{lrrrrr}
\hline Compound & $H L-60$ & SMMC-7721 & A-549 & MCF-7 & SW480 \\
\hline $\mathbf{1}$ & 7.8 & 9.8 & 10.8 & 11.6 & 15.8 \\
$\mathbf{2}$ & 14.2 & 10.4 & 7.7 & 9.6 & 11.6 \\
Cisplatin $^{\mathrm{a}}$ & 1.0 & 4.3 & 5.1 & 15.4 & 15.4 \\
\hline
\end{tabular}

apositive control.

line), SMMC-7721 (hepatocellular carcinoma cell line), HL-60 (human myeloid leukemia cell line), PANC-1 (pancreatic cancer cell line) and A-549 (lung cancer cell line). Assays were performed as described previously. ${ }^{16}$

\section{Supplementary}

1D and 2D NMR and MS spectra of compounds 1 and $\mathbf{2}$ are available in Supplementary Information.

\section{ACKNOWLEDGEMENTS}

This project was financially supported by the National Natural Science Foundation of China (U1132607, 81102346) and Youth Innovation Promotion Association of CAS (2011312D11019).

1 Tan, R. X. \& Zou, W. X. Endophytes: a rich source of functional metabolites. Nat. Prod Rep. 18, 448-459 (2001).

2 Kharwar, R. N., Mishra, A., Gond, S. K., Stierle, A. \& Stierle, D. Anticancer compounds derived from fungal endophytes: their importance and future challenges. Nat. Prod. Rep. 28, 1208-1228 (2011).

3 Xiao, Z. E. et al. Asperterpenols A and B, new sesterterpenoids isolated from a mangrove endophytic fungus Aspergillus sp. 085242. Org. Lett. 15, 2522-2525 (2013)

4 Capasso, R. et al. Ascochalasin, a new cytochalasin from Ascochyta heteromorpha. J. Nat. Prod. 51, 567-571 (1988).

5 Aldridge, D. C., Armstrong, J. J., Speake, R. N. \& Turner, W. B. The structures of cytochalasins A and B. J. Chem. Soc. C Org. 1667-1676 (1967).

6 Evidente, A., Andolfi, A., Vurro, M., Zonno, M. C. \& Motta, A. Cytochalasins Z1, Z2 and Z3, three 24-oxa[14]cytochalasans produced by Pyrenophora semeniperda. Phytochemistry 60, 45-53 (2002)

7 Konig, G. M., Wright, A. D., Aust, H. J., Draeger, S. \& Schulz, B. Geniculol, a new biologically active diterpene from the endophytic fungus Geniculosporium sp.1. J. Nat. Prod. 62, 155-157 (1999).

8 Izawa, Y., Hirose, T., Shimizu, T., Koyama, K. \& Natori, S. Six new 10-pheynl[11]cytochalasans, cytochalasins N-S from Phomopsis sp. Tetrahedron 45, 2323-2335 (1989)

9 Steyn, P. S., van Heerden, F. R. \& Rabie, C. Cytochalasins E and K, toxic metabolites from Aspergillus clavatus. J. Chem. Soc. Perk. Trans. 1 541-544 (1982).

10 Liu, R. et al. 10-Phenyl-[12]-cytochalasins Z7, Z8, and Z9 from the marine-derived fungus Spicaria elegans. J. Nat. Prod. 69, 871-875 (2006).

11 Chen, Z. M. et al. New cytochalasins from the marine-derived fungus Xylaria sp. SCSIO 156. Helv. Chim. Acta 94, 1671-1676 (2011).

12 Zhang, D. W. et al. Periconiasins A-C, new cytotoxic cytochalasans with an unprecedented 9/6/5 tricyclic ring system from endophytic fungus Periconia sp. Org. Lett. 15, 1674-1677 (2013).

13 Pongcharoen, W., Rukachaisirikul, V., Phongpaichit, S., Rungjindamai, N. \& Sakayaroj, J. Pimarane diterpene and cytochalasin derivatives from the endophytic fungus Eutypella scoparia PSU-D44. J. Nat. Prod. 69, 856-858 (2006).

14 Lingham, R. B. et al. L-696,474, a novel cytochalasin as an inhibitor of HIV-1 protease. III: biological activity. J. Antibiot. 45, 686-691 (1992).

15 Evidente, A., Andolfi, A., Vurro, M., Zonno, M. C. \& Motta, A. Cytochalasins Z4, Z5, and Z6, three new 24-Oxa[14] cytochalasans produced by Phoma exigua var. heteromorpha. J. Nat. Prod. 66, 1540-1544 (2003).

16 Niu, S. W. et al. Lobophorins $E$ and F, new spirotetronate antibiotics from a South China Sea-derived Streptomyces sp. SCSIO 01127. J. Antibiot. 64, 711-716 (2011).

Supplementary Information accompanies the paper on The Journal of Antibiotics website (http://www.nature.com/ja) 